CURRENT

Jurnal Kajian Akuntansi dan Bisnis Terkini

https://current.ejournal.unri.ac.id

\title{
ANALISIS PENINGKATAN KINERJA PEMERINTAH DESA PADA DESA DI KABUPATEN MERANTI
}

\author{
Vera Oktari $^{1^{*}}$, Ulfa Afifah ${ }^{2}$, Arumega Zarefar ${ }^{3}$, Mayla Khoiriyah ${ }^{4}$ \\ ${ }^{123}$ Program Studi Akuntansi, Fakultas Ekonomi dan Bisnis, Universitas Riau, Pekanbaru \\ *Email: veraoktari@lecturer.unri.ac.id
}

\section{Keywords \\ Organizational \\ Commitment, Community \\ Participation, Apparatus \\ Competence}

\section{Article informations}

Received:

2020-08-28

Accepted:

2021-01-07

Available Online:

2021-03-26

\begin{abstract}
In improving its performance, the village government requires to have organizational commitment that supported by apparatus competency and controlled through community participation. The purpose of this study was to examine the effect of organizational commitment, community participation, and apparatus competence on village government performance. 200 data collected from questionnaires will be analyzed to identify organizational commitment, community participation, and apparatus competency towards the village government performance. Data analyzed by using SPPS version 25.0. the result of data processing found that organizational commitment, community participation, and apparatus competency affects the village government performance, and the organizational commitment is needed to improve apparatus competency by educating and training its human resources, also the transparency as the form of responsibility of the village government to citizen.
\end{abstract}

\section{PENDAHULUAN}

Penilaian kinerja merupakan kegiatan untuk menentukan serta melihat efektivitas pelaksanaan kegiatan organisasi, dan untuk melihat apakah kegiatan yang telah direncanakan tersebut berhasil atau tidak, serta untuk memberikan tindak lanjut dalam rangka peningkatan mutu pada kegiatan-kegiatan masa yang akan datang (Raharja, et.al 2015; Kloot 1999; Mowday and Steers 1979). Pengukuran kinerja berfokus kepada bagaimana distribusi dana yang dikelola untuk memenuhi kepentingan masyarakat umum, bebas dari terjadinya penyelewengan.

Saat ini kinerja pemerintahan desa masih menjadi sorotan masyarakat luas. Ombudsman Republik Indonesia yang merupakan Lembaga Negara yang memiliki wewenang mengawasi jalannya pelaksanaan pelayanan publik, masih menerima banyak pengaduan dari masyarakat terkait pengelolaan dana desa (www.ombudsman.go.id). Banyaknya pengaduan masyarakat ini menggambarkan bahwa kinerja pemerintah desa terkait dana desa yang 
diterima masih perlu diperbaiki.

Untuk mendukung terciptanya hasil kerja yang optimal, maka dibutuhkan peran seluruh pihak di organisasi dalam melakukan pengawasan dan penciptaan pengelolaan pekerjaan yang baik dan sesuai dengan standar yang berlaku. Untuk mendukung terlaksananya pengelolaan pekerjaan yang baik, setiap aparatur dituntut memiliki sikap terhadap tugas dan tanggungjawabnya. Komitmen organisasi sering digambarkan sebagai sikap individu, yang mencerminkan perasaan suka atau tidak sukanya terhadap organisasinya (Guan and Hsu 2020; Jehanzeb and Mohanty 2019; Lubis 2019; Nursito dan Faeni 2019; Rulyanti 2016; Sujana 2012; Taurisa dan Ratnawati 2012; Mowday and Steers, 1979). Aparatur yang berkomitmen akan memiliki loyalitas kepada organisasi dan menepikan kepentingan pribadinya. Komitmen organisasi menjadikan seorang aparatur memiliki keyakinan terhadap organisasinya, sehingga mau melaksanakan pekerjaan dengan sungguhsungguh dan sekuat tenaga, serta saling menjaga agar tidak terjadi konflik peran dalam organisasi.

Salah satu ciri adanya komitmen organisasi dalam mencapai kinerja adalah dengan memberikan sumber daya manusia didalamnya pendidikan dan pelatihan sebagai upaya peningkatan mutu aparatur, sehingga usaha pencapaian tujuan organisasi dapat dicapai secara optimal. Dibutuhkan kompetensi diri bagi seluruh aparatur dalam memegang dan menjalankan tugas atau tanggung jawab. Kompetensi yang dimaksud adalah kemampuan meliputi pengetahuan, keahlian, dan perilaku yang baik, sehingga aparat tersebut dapat diberikan tanggung jawab. Kompetensi merupakan karakteristik dasar yang harus dimiliki seseorang dalam mengerjakan suatu tugas meliputi kemampuan intelektual dan kemampuan fisik (Robin 2007; Sedarmayanti 2008).

Partisipasi masyarakat sangat dibutuhkan untuk keberhasilan pembangunan di desa menuju ke arah yang lebih baik, peran dan kinerja pemerintahan desa juga sangat diharapkan untuk dapat menjalankan tugas pokok memimpin dan mengkoordinasikan dalam melaksanakan urusan rumah tangga desa, melakukan pembinaan dan pembangunan masyarakat dan membina perekonomian desa.

Peran pemerintah desa sudah dikatakan baik terutama dalam masalah pembangunan desa, dimana pemerintah desa telah melakukan berbagai upaya agar pembangunan di desa dapat berkembang dan menuju ke arah yang lebih baik melalui berbagai macam cara, seperti melalui musyawarah perencanan pembangunan desa sehingga menghasilkan berbagai program-program pembangunan, melalui komunikasi politik dengan pemerintah daerah untuk suatu kegiatan pembangunan. Tetapi tanpa adanya partisipasi dari masyarakat dalam setiap 
kegiatan pembangunan yang ada, maka akan mengalami hambatan, bahkan tidak akan dapat terwujud atau dikatakan tidak berhasil, karena terdapat beberapa kondisi dan keadaan masyarakat yang menolak untuk berpartisipasi bahkan mengatakan tidak terlibat baik secara langsung maupun secara tidak langsung dalam kegiatan pembangunan desa. Seharusnya sebagai masyarakat harus berpartisipasi dalam pembangunan desa, mengingat bahwa kegiatan pembangunan di desa bukan untuk kepentingan beberapa orang atau sekelompok orang saja melainkan untuk kepentingan dan kebutuhan banyak orang. Peranan masyarakat dalam penyelenggaraan kegiatan pemerintahan akan memudahkan pemerintah dalam menyelesaikan tugas dan kewajibannya selaku aparatur desa untuk dapat terlibat dalam pengambilan keputusan dan merupakan indikator yang cukup penting.

Variabel bebas dalam penelitian ini yang sangat menarik untuk dilakukan penelitian secara lebih mendalam yaitu kompetensi aparatur. Karena kompetensi dari aparatur penyelenggara pemerintahan desa yang mayoritas mempunyai tingkat pengetahuan, pengalaman dan keterampilan yang masih terbilang rendah, sudah diberi amanat dalam mengelolaan dana desa yang terbilang cukup fantastis. Begitu juga dengan implementasi Undang-Undang Nomor 6 Tahun 2014, yang mana undang-undang tersebut masih tergolong baru disahkan dan diundangkan, sedangkan pelaksanaannya harus disegerakan mengingat komitmen pemerintah pusat dalam menggerakkan roda perekonomian di tingkat desa melalui penggelontoran dana desa di seluruh Indonesia.

Penelitian ini mengacu kepada penelitian sebelumnya diantaranya adalah Wardana dan Astika (2015) yang meneliti tentang pengaruh kompetensi pada akuntanbilitas kinerja instansi pemerintah, Sujana (2012) tentang pengaruh kompetensi dan komitmen organisasi terhadap kinerja pemerintah serta Adna (2019) tenrang pengaruh partisipasi masyarakat terhadap pengelolaan dana desa. Sehingga, penelitian ini bertujuan untuk menguji pengaruh komitmen organisasi, partisipasi masyarakat dan kompetensi aparatur terhadap kinerja pemerintah desa. Dengan adanya penelitian ini, diharapkan dapat memberikan gambaran tentang pengaruh komitmen organisasi, partisipasi masyarakat dan kompetensi aparatur terhadap kinerja pemerintah desa, sehingga pemerintah desa dapat mempertimbangkan hasil penelitian ini dalam menentukan standar penilaian kinerja.

\section{PENGEMBANGAN HIPOTESIS}

\section{Pengaruh Komitmen Organisasi Terhadap Kinerja Pemerintah Desa}

Komitmen juga dapat dilihat dari loyalitas. Seseorang yang memiliki loyalitas terhadap organisasinya akan memberikan yang terbaik dalam performanya. Loyalitas juga 
dapat dilihat dari sikap positif yang ditunjukkan terhadap organisasinya, peningkatan kinerja individu dalam organisasi, serta keyakinan dalam pencapaian tujuan organisasi (Kuryanto, 2011). Komitmen organisasi berpengaruh kepada kinerja organisasi. Semakin berkomitmen orang-orang yang berada dalam organisasi, maka akan semakin baik kinerjanya (Porter dan Steers dalam Luthan, 1992:125). Berdasarkan uraian di atas, hipotesis yang dapat dikembangkan adalah sebagai berikut:

\section{H1: Komitmen Organisasi berpengaruh terhadap Kinerja Pemerintah Desa.}

\section{Pengaruh Partisipasi Masyarakat Terhadap Kinerja Pemerintah Desa}

Undang-undang nomor 6 tahun 2014 tentang desa dan Undang-undang nomor 23 tahun 2014 tentang pemerintah daerah menyatakan bahwa masyarakat dapat berpartisipasi dalam pengeloaan desa/daerah dengan mengusulkan dan memberi masukan kepada kepala dan perangkat desa terkait penyusunan peraturan desa, serta mengawasi kinerja kepala desa. Adanya partisipasi masyarakat dalam pengelolaan desa akan menjadikan meningkatnya akuntabilitas dan pertanggungjawaban kepala desa terkait pengelolaan dana desa, sehingga kinerja pemerintah desa akan baik. Berdasarkan uraian di atas, hipotesis yang dapat dikembangkan adalah sebagai berikut:

\section{H1: Partisipasi Masyarakat berpengaruh terhadap Kinerja Pemerintah Desa.}

\section{Pengaruh Kompetensi Aparatur terhadap Kinerja Pemerintah Desa}

Individu yang memiliki kompetensi diri yang baik, dapat mempengaruhi kinerja diri dan organisasinya. Sujana (2012) dalam penelitiannya menyatakan bahwa kompetensi yang rendah akan mempengaruhi kinerja. Kompetensi seorang individu dapat dilihat dari tingkat pengetahuannya, skill, dan sikapnya. Frinki dan Klimoski (2004) menyatakan bahwa salah satu faktor pendukung kinerja adalah apabila sebuah organisasi didukung oleh sumber daya manusia yang kompeten. Berdasarkan uraian di atas, hipotesis yang dapat dikembangkan adalah sebagai berikut:

\section{H3: Kompetensi Aparatur berpengaruh terhadap Kinerja Pemerintah Desa.}

\section{METODE PENELITIAN}

\section{Populasi dan Sampel}

Penelitian ini dilakukan di Kabupaten Meranti pada tahun 2020. Populasi penelitian ini adalah seluruh Pemerintahan Desa Kabupaten Meranti, sedangkan sampel penelitian ini ditentukan dengan metode purposive sampling, dimana dibuat beberapa kriteria untuk dasar pengambilan data. Adapun kriteria responden yang ditetapkan yakni, pertama responden 
merupakan bagian dari Pemerintahan Desa yang ada di Kabupaten Meranti. Kedua, Responden memiliki peranan yang berhubungan dengan pengelolaan keuangan desa atau pengambil keputusan dalam penggunaan dana desa.

Responden mengembalikan kuesioner yang disebarkan tepat waktu. Populasi yang digunakan seluruh auditor internal pada inspektorat Provinsi Riau yang berjumlah 47 orang (sumber: www.inspektorat.riau.go.id). Auditor disini berarti seluruh aparat inspektorat yang melakukan pemeriksaan keuangan di inspektorat Provinsi Riau. Sampel dalam penelitian ini adalah seluruh populasi (sensus). Alasan penggunaan sensus karena elemen-elemen populasi yang relatif sedikit.

\section{Teknik Pengumpulan Data}

Dalam memperoleh data, penelitian ini menggunakan kuesioner yang berisi pertanyaan-pertanyaan yang mewakili variabel penelitian. Kuesioner yang digunakan merupakan kuesioner yang sudah digunakan pada penelitian-penelitian terdahulu yang meneliti variabel yang sama.

\section{Metode Analisis Data}

Data penelitian diuji mengunggunakan uji $\mathrm{T}$ yang diolah menggunakan SPSS Versi 24. Dari hasil pengujian analisis regresi berganda, diperoleh formula sebagai berikut:

$$
\mathrm{Y}=\mathrm{a}+\beta 1 \mathrm{X} 1+\beta 2 \mathrm{X} 2+\beta 3 \mathrm{X} 3+\mathrm{e}
$$

Dimana:

$$
\begin{array}{ll}
\mathrm{Y} & =\text { Kinerja Pemerintah Desa } \\
\mathrm{a} & =\text { Konstanta } \\
\mathrm{b} & =\text { Koefisien Regresi } \\
\mathrm{X} 1 & =\text { Komitmen Organisasi } \\
\mathrm{X} 3 & =\text { Partisipasi Masyarakat } \\
\mathrm{X} 2 & =\text { Kompetensi Aparatur } \\
\mathrm{e} & =\text { Erorr }
\end{array}
$$

\section{HASIL PENELITIAN DAN PEMBAHASAN}

\section{Hasil Uji Statistik Deskriptif}

Tabel berikut menunjukkan hasil statistik deskriptif berdasarkan data yang diperoleh dari responden. 


\section{Tabel 1}

\section{Hasil Uji Statistik Deskriptif}

\begin{tabular}{lccccc}
\hline & N & Min & Max & Mean & Std. Deviation \\
\hline Komitmen Organisasi (X1) & 200 & 2 & 5 & 3.724 & 0.849 \\
Partisipasi Masyarakat (X2) & 200 & 2 & 5 & 3.8 & 0.82 \\
Kompetensi Aparatur (X3) & 200 & 2 & 5 & 3.812 & 0.798 \\
Kinerja Pemerintah Desa (Y) & 200 & 2 & 5 & 3.759 & 0.792 \\
Valid N (listwise) & 200 & & & & \\
\hline
\end{tabular}

Sumber: Data Olahan SPSS (2020).

Dalam statistik deskriptif diketahui komitmen organisasi (X1) dengan nilai minimun 2, nilai maksimum sebesar 5. Nilai tengah atau mean adalah 3.724 dengan standar deviasi 0.849. Partisipasi Masyarakat (X2) dengan nilai minimun 2, nilai maksimum sebesar 5. Nilai tengah atau mean adalah 3.8 dengan standar deviasi 0.82. Kompetensi Aparatur (X3) dengan nilai minimun 2, nilai maksimum sebesar 5. Nilai tengah atau mean adalah 3.812 dengan standar deviasi 0.798. Kinerja Pemerintah Desa (Y) dengan nilai minimun 2, nilai maksimum sebesar 5. Nilai tengah atau mean adalah 3.759 dengan standar deviasi 0.792 .

\section{Hasil Uji Analisis Regresi Linear Berganda}

Berikut ini adalah hasil pengujian analisis regresi linear berganda dengan menggunakan SPSS untuk pengujian seluruh hipotesis.

\section{Tabel 2}

\section{Hasil Uji Analisis Regresi Linear Berganda}

\begin{tabular}{llcccccc}
\hline \multirow{2}{*}{ Model } & \multicolumn{2}{c}{ Unstandardized Coefficients } & $\begin{array}{c}\text { Standardized Coefficients } \\
\text { B }\end{array}$ & Std. Error & T & Sig. \\
\hline 1 & (Constant) & 8.979 & 2.132 & & 4.212 & .000 \\
& KO & .483 & .063 & .454 & 7.702 & .000 \\
& PM & .437 & .108 & .240 & 4.055 & .000 \\
& KA & .293 & .073 & .256 & 3.989 & .000 \\
\hline
\end{tabular}

Sumber: Data Olahan SPSS (2020).

\section{Pengaruh Komitmen Organisasi Terhadap Kinerja Pemerintah Desa}

Dari hasil pengolahan data dapat diketahui signifikan variabel komitmen organisasi (X1) memiliki nilai signifikan sebesar 0,000 (kecil dari $\alpha=5 \%$ ). Selain itu, pengaruh komitmen organisasi (X1) terhadap kinerja pemerintah desa memiliki t hitung sebesar 7.702. Oleh karena t hitung > t tabel (7.702>1.97208), maka dapat disimpulkan bahwa H1 diterima, artinya secara parsial ada pengaruh signifikan antara komitmen organisasi terhadap kinerja pemerintah desa.

Komitmen organisasi sangat dibutuhkan dalam mempertahankan loyalitas serta rasa memiliki dan keinginan diri untuk mempertahankan keanggotaan dalam organisasi. Begitu 
pula komitmen aparatur desa, dimana didalam diri aparatur perlu ditanamkan komitmen yang tinggi terhadap organisasinya, karena dengan komitmen aparatur desa yang tinggi mempengaruhi dan meningkatkan kinerja aparatur desa itu sendiri.

Pegawai atau karyawan dengan komitmen yang tinggi dapat diharapkan akan menunjukkan kinerja yang optimal. Seseorang yang bergabung dalam organisasi pada sebuah perusahaan dituntut adanya komitmen dalam dirinya (Halim, 2012). Hasil penelitian ini didukung oleh penelitian sebelumnya yang dilakukan oleh Fitriana (2015) dan Putri (2013) yang menunjukkan bahwa komitmen organisasi berpengaruh terhadap kinerja pemerintah desa.

\section{Pengaruh Partisipasi Masyarakat terhadap Kinerja Pemerintah Desa}

Dari hasil pengolahan data diketahui Jika dilihat dari signifikan variabel partisipasi masyarakat (X2) memiliki nilai signifikan sebesar 0,000 (kecil dari $\alpha=5 \%$ ). Selain itu, pengaruh partisipasi masyarakat (X2) terhadap kinerja pemerintah desa memiliki t hitung sebesar 4.055. Oleh karena $t$ hitung $>\mathrm{t}$ tabel (4.055>1.97208), maka dapat disimpulkan bahwa H2 diterima, artinya secara parsial ada pengaruh signifikan antara partisipasi masyarakat terhadap kinerja pemerintah desa.

Hasil ini memberikan gambaran bahwa turut sertanya masyarakat berpartisipasi dalam setiap kegiatan desa akan mempengaruhi keberhasilan dan pembangunan desa. Hasil penelitian Karim, et.al (2019) juga menyimpulkan bahwa banyaknya hasil yang diperoleh dalam pelaksanaan pembangunan baik secara fisik maupun non fisik, karena peranan masyarakat merupakan indikator yang penting dalam pengambilan keputusan terhadap penyelenggaraan kegiatan pemerintahan, dimana partisipasi masyarakat akan memudahkan pemerintah dalam menyelesaikan tugas dan kewajibannya selaku aparatur desa.

\section{Pengaruh Kompetensi Aparatur terhadap Kinerja Pemerintah Desa}

Dari hasil pengolahan data dapat diketahui Jika dilihat dari signifikan variabel kompetensi aparatur (X3) memiliki nilai signifikan sebesar 0,000 (kecil dari $\alpha=5 \%$ ). Pengaruh kompetensi aparatur (X3) terhadap kinerja pemerintah desa memiliki t hitung sebesar 3.989. Oleh karena thitung > t tabel (3.989>1.97208), maka dapat disimpulkan bahwa H3, diterima, artinya secara parsial ada pengaruh signifikan antara kompetensi aparatur terhadap kinerja pemerintah desa.

Menurut Muhammad Fadhil (2016) kompetensi sumber daya manusia juga dapat mempengaruhi kinerja. Untuk menciptakan good governance pada pemerintah desa, kompetensi sumber daya manusia (SDM) juga sangat menentukan keberhasilan pemerintah 
desa, karena kompetensi sumber daya manusia menurut Sutrisno (2009) dalam Tua (2015) adalah kemampuan sumber daya manusia untuk melaksanakan tugas dan tanggungjawab yang diberikan kepadanya dengan bekal pendidikan, pelatihan, dan pengalaman yang cukup memadai.

\section{Analisis Koefisien Determinasi}

\section{Tabel 3}

\section{Hasil Uji R Square}

\begin{tabular}{cc|c|c|c|c}
\hline Model & $\mathbf{R}$ & R Square & Adjusted R Square & $\begin{array}{c}\text { Std. Error of the } \\
\text { Estimate }\end{array}$ & Durbin-Watson \\
1 & $.880^{\mathrm{a}}$ & .774 & .771 & 3.81317 & 2.120 \\
\hline
\end{tabular}

a. Predictors: (Constant), KA, KO, PM

b. Dependent Variable: KPD

\section{Sumber: Data Olahan SPSS (2021)}

Nilai R2 ( $R$ Square) diketahui sebesar 0,774 atau $77.4 \%$ menunjukan bahwa persentase sumbangan pengaruh variabel independen (komitmen organisasi, partisipasi masyarakat, dan kompetensi aparatur) terhadap variabel dependen (kinerja pemerintah desa) sebesar $77.4 \%$. dengan kata lain, masih terdapat pengaruh faktor-faktor lain yang tidak dimasukkan dalam model penelitian ini terhadap kinerja pemerintah desa sebesar 0,226 atau $22,6 \%$.

\section{SIMPULAN}

Penelitian ini memiliki tiga temuan utama. Temuan pertama diketahui bahwa terdapat pengaruh signifikan yang diberikan oleh variabel komitmen organisasi terhadap kinerja pemerintah desa. Sejalan dengan penelitian yang dilakukan oleh Halim (2012), Fitriana (2015), dan Putri (2013), dapat disimpulkan bahwa untuk memperoleh loyalitas seorang aparatur, maka organisasi harus dapat menimbulkan komitmen aparatur desa untuk bekerja mengedepankan pencapaian tujuan organisasi dan mengesampingkan tujuan pribadinya.

Temuan kedua, berdasarkan hasil pengolahan data diketahui bahwa partisipasi masyarakat berpengaruh signifikan terhadap kinerja pemerintah desa sejalan dengan temuan penelitian milik Cahyadi (2009) dan Tumber (2017), partisipasi masyarakat sangat penting dan dibutuhkan dalam mengawasi pelaksanaan pembangunan oleh aparatur agar dapat mencapai tujuan berupa peningkatan kesejahteraan masyarakat desa.

Temuan ketiga, yaitu diketahui terdapat pengaruh signifikan kompetensi aparatur terhadap kinerja pemerintah desa, yang sejalan dengan hasil penelitian Fadhil (2016). Edison (2016) menyatakan bahwa dibutuhkan pengetahuan dan kemampuan yang diperlukan dalam 
mencari solusi, serta sikap dan inisiatif dalam bekerja pada diri anggota organisasi untuk mencapai tujuan organisasi.

Pemerintah diberikan tanggung jawab dalam melaksanakan program dan kegiatan menggunakan dana yang berasal dari masyarakat, dan diharapkan dapat dinikmati kembali oleh masyarakat. Kinerja pemerintah menjadi gambaran bagaimana pengelolaan yang telah dilakukan aparatur, sehingga perlu dilakukan peningkatan setiap waktunya. Penelitian ini menemukan bahwa komitmen organisasi, partisipasi masyarakat, dan kompetensi aparatur merupakan beberapa faktor penting yang mempengaruhi kinerja pemerintah desa, sehingga perlu diperhatikan oleh pemerintah terutama dalam menghasilkan peraturan dan perundangundangan yang akan menjadi dasar pemerintah melaksanakan tugasnya.

Penelitian ini juga memiliki beberapa keterbatasan yang dapat menjadi panduan bagi penelitian dengan topik yang sama selanjutnya. Penelitian ini dilakukan hanya pada satu kabupaten, dan selain itu masih banyak faktor-faktor lain yang mempengaruhi kinerja pemerintah desa yang dapat diteliti lebih lanjut.

\section{REFERENSI}

M Fadhil, M. (2016). Pengaruh Kompetensi Sumber Daya Manusia terhadap Kinerja Pegawai pada Balai Latihan Kerja Industri Makassar. Jurnal Pengembangan Sumber Daya Insani. Volume 1 Nomor 1.

Fitriana, D. (2015). Pengaruh Sumber Daya Manusia, Informasi Keuangan Desa dan Komitmen Organisasi Terhadap Kinerja Kepala Desa Dengan Pengelolaan Keuangan Desa Sebagai Variabel Intervening. Thesis, Universitas Airlangga.

Guan, B. \& Hsu, C. (2020). The Role of Abusive Supervision and Organizational Commitment on Employees' Information Security Policy Noncompliance Intention, Employees' ISP Noncompliance Intention.

Halim, R. (2012). Pengaruh Komitmen Organisasi Dan Peranan Kepemimpinan Dalam Meningkatkan Pengelolaan Keuangan Daerah Pada Dinas Pendapatan, Pengelolaan Keuangan Dan Asset Kabupaten Banggai Kepulauan. Jurnal Academica Fisip Untad, Vol. 04.

Jehanzeb, K. \& Mohanty, J. (2018). Impact of Employee Development on Job Satisfaction and Organizational Commitment: Person-Organization Fit as Moderator. International Journal of Training and Development. Vol.22.

Karim, et al. (2019). Pengaruh Kompetensi Aparat Desa, Komitmen Organisasi dan Partisipasi Masyarakat Terhadap Keberhasilan Pengelolaan Keuangan Desa (Studi Kasus Desa Buntongi Kec. Ampana Kota Kab. Tojo Una Una). Agribusiness Journal. Volume 13 Nomor 2.

Kloot, L. (1999). Performance Measurement and Accountability in Victorian Local Government. International Journal of Public Sector Management, 12 (7): 565-584. 
Lubis, R. F. A. (2019). Pengaruh Komitmen Organisasi, Kapasitas Individu, Asimetri Informasi dan Ketidakpastian Lingkungan terhadap Budgetary Slack pada Pemerintah Kota Medan. Repositori Institusi USU.

Luthans, F. (2011). Organizational Behavior. 12th Edition. New York: McGraw Hill Inc.

Mangkunegara, A. P. (2005). Perilaku dan Budaya Organisasi. Penerbit PT Refika Aditama, Bandung.

Manning, G. \& Kent, C. (2003). The Art of Leadership. New York: McGraw-Hill.

Mowday, R. T., R. M. Steers \& L. W. Porter. (1979). The Measurement of Organizational Commitment. Journal of Vocational Behavior, 14: 224-247.

Nursito \& Faeni, D. (2019). Analysis of Effect of Organization Commitment, Microfinance and Accountability on Poverty Reduction in the Farmers. International Journal of Recent Technology and Engineering. Volume 8.

Putri, G, Y. (2013). Pengaruh Komitmen Organisasi Dan Sistem Pengendalian Intren Pemerintah (SPIP) Terhadap Kinerja Manajerial SKPD (Studi Empiris pada Satuan Kerja Perangkat Daerah Kota Padang). Jurnal Akuntansi, Volume 1 Nomor 1.

Raharja, G. P., Herawati, N. T. \& Purnamawati, I. G. A. (2015). Pengaruh Akuntabilitas, Partisipasi Masyarakat dan Pengawasan Internal Terhadap Kinerja Organisasi (Pada Dinas Pekerjaan Umum Kabupaten Buleleng). e-journal S1 Ak Universitas Pendidikan Ganesha Jurusan Akuntansi S1, Volume 3 No.1.

Rulyanti, D. (2016). Pengaruh Regulasi, Komitmen Organisasi, Komunikasi dan Sumber Daya Manusia terhadap Kinerja Pemerintah Desa dengan Pengelolaan Keuangan Desa sebagai Variabel Intervening (Studi pada Pemerintah Desa di Kabupaten Bondowoso. Tesis. Universitas Jember.

Robbins S.P \& Judge. (2007). Perilaku Organisasi. Salemba Empat. Jakarta.

Sedarmayanti. (2008). Manajemen Sumber Daya Manusia, Jakarta: Grasindo.

Sujana, E. (2012). Pengaruh Kompetensi, Motivasi, Kesesuaian Peran dan Komitmen Organisasi Terhadap Kinerja Auditor Internal Inspektorat Pemerintah Kabupaten (Studi Pada Kantor Inspektorat Kabupaten Badung Dan Buleleng). Jurnal Ilmiah Akuntansi dan Humanika. Volume 2 nomor 1.

Sutrisno, E. (2009). Manajemen Sumber Daya Manusia. Jakarta: Kencana Prenada Media Group.

Taurisa, C. M. \& Ratnawati, I. (2012). Analisis Pengaruh Budaya Organisasi dan Kepuasan Kerja Terhadap Komitmen Organisasional Dalam Meningkatkan Kinerja Karyawan (Studi Pada PT. Sido Muncul Kaligawe Semarang). Jurnal Bisnis dan Ekonomi (JBE), Vol. 19 No. 2: 170-187.

Tua, M. P. (2015). Pengaruh Good Governance, Kompetensi Sumber Daya Manusia dan Sistem Pengendalian Intern terhadap Kualitas Informasi Laporan Keuangan (Studi Empiris pada Skpd Kota Dumai). Jurnal Online Mahasiswa. Fakultas Ekonomi 
Universitas Riau.

Keputusan Kepala LAN Nomor 239/IX/6/8/2003 tentang Perbaikan Pedoman Penyusunan Pelaporan Akuntabilitas Kinerja Instansi Pemerintah.

Peraturan Menteri Dalam Negeri nomor 13 tahun 2006 tentang Pengelolaan Keuangan Daerah Peraturan Menteri Dalam Negeri nomor 113 tahun 2014 tentang Pengelolaan Keuangan Desa Undang-Undang Nomor 23 Tahun 2014 tentang Pemerintahan Daerah Undang-Undang Nomor 6 Tahun 2014 tentang Desa www.ombudsman.go.id/artikel/r/artikel--ombudsman--banyak-masalah-terkait-dana-desa 